\title{
Primary clear cell adenocarcinoma of duodenum
}

\author{
Tadashi Terada* \\ Department of Pathology, Shizuoka City Shimizu Hospital, Shizuoka, Japan
}

Received: December 30, 2016

Accepted: February 28, 2016

Online Published: March 15, 2016

DOI: $10.5430 /$ crcp.v3n2p47

URL: http://dx.doi.org/10.5430/crcp.v3n2p47

\begin{abstract}
Backgrounds: Clear cell adenocarcinoma (CCA) of duodenum has not been reported. Aims: To report the first case of CCA of duodenum.

Case: A 76-year-old woman presented epigastralgia, and upper GI endoscopy revealed an ulcerated tumor in the $1^{\text {st }}$ portion (next to stomach) of duodenum close to pylorus (remote from pylorus by $2 \mathrm{~cm}$ ). No tumor was seen in duodenal papilla. Biopsy from the lesion showed proliferation and invasion of high-grade carcinoma cells with very clear cytoplasma but without glandular structures. No signet-ring carcinoma cells were seen. Histochemically, mucus stains showed no mucins but suggested glycogens. Immunohistochemically, tumor cells were positive for cytokeratin (CK)7, CK18, CK19, CEA, CA19-9, p53, MUC1, and Ki67 (labeling index $=36 \%$ ), but negative for CD45, CK34BE12, CK5, CK6, CK20, vimentin, CA125, CDX-2, HepPar1, AFP, PSA, CD10, renal cell carcinoma (RCC) markers, PSA, AMACR, HER2, S100 protein, TTF-1, NSE, NCAM, synaptophysin, chromogranin, MUC2, MUC5AC, MUC6, estrogen receptor and progesterone receptor.

Conclusion: The first case of primary CCA of duodenum is reported.
\end{abstract}

Key Words: Duodenum, Clear cell adenocarcinoma

\section{INTRODUCTION}

Primary malignant tumors of small intestine including duodenum are very rare. ${ }^{[1,2]}$ Malignant tumors composed of clear malignant cells can occur in any locations, ${ }^{[1-7]}$ but most representative are clear cell renal cell carcinoma $(\mathrm{RCC})^{[3]}$ and clear cell adenocarcinoma (CCA) of female genital organs. ${ }^{[4]}$ $\mathrm{CCA}$ is reported in the stomach, ${ }^{[5]}$ but has not been reported in duodenum.

\section{CASE REPORT}

A 76-year-old woman presented epigastralgia, and upper GI endoscopy revealed an ulcerated tumor in duodenum (see Figure 1A) in the 1st portion (next to stomach) of duodenum close to pylorus (remote from pylorus by $2 \mathrm{~cm}$ ). No tumor was seen in duodenal papilla. Seven relatively large punch biopsies taken from the lesion showed proliferation and invasion of high-grade carcinoma cells with very clear cytoplasma but without glandular structures (see Figure 1BD). Almost all carcinoma cells had clear cytoplasma. Tumor nuclei were located in central cytoplasm, and no signet-ring carcinoma cells were seen. Histochemically, PAS, d-PAS, alcian blue, and colloidal iron stains showed no significant mucins but suggested a small amount of glycogen which was stained as granular by PAS stain (see Figure 1E) and was abolished in d-PAS stain (not shown). Immunohistochemical study was carried out with the use of envision method. ${ }^{[8]}$ The tumor cells were positive for cytokeratin (CK)7 (see Figure 1F), CK18, CK19, CEA (see Figure 1G), CA19-9, p53, MUC1 (see Figure 1H), and Ki67 (labeling index = 36\%), but negative for CD45, CK34BE12, CK5, CK6, CK20, vi-

\footnotetext{
*Correspondence: Tadashi Terada; Email: piyo0111jp@yahoo.co.jp; Address: Department of Pathology, Shizuoka City Shimizu Hospital, Miyakami 1231 Shimizu-Ku, Shizuoka 424-8636, Japan.
}

Published by Sciedu Press 
mentin, CA125, CDX-2, HepPar1, AFP, PSA, CD10, RCC markers, PSA, AMACR, HER2, S100 protein, TTF-1, NSE, NCAM, synaptophysin, chromogranin, MUC2, MUC5AC, MUC6, estrogen receptor (ER) and progesterone receptor $(\mathrm{PgR})$. The diagnosis of CCA of duodenum was made. No other tumor was seen in various imaging techniques. No surgical intervention was carried out because the patient denied it and also because the cancer was in advanced stage (Stage $3)$. The patient is now treated by chemotherapy.
Figure 1. Endoscopic (A), histological (B,C,D), histochemical (E) and Immunohistochemical $(\mathrm{F}, \mathrm{G}, \mathrm{H})$ findings of the tumor.

A: Upper GI endoscopy shows ulcerated tumor (arrow) in duodenum; B: Low power view of the biopsy. Carcinoma cells without differentiation are seen (arrows). HE, $\times 40$; $C$ : Medium power view shows apparent carcinoma with atypia and clear cytplasma. HE, $\times 200$; D: High power view shows high-grade atypical features, cancer cell characteristics, and clear cytoplasms. HE, $\times 300$; G: PAS staining showed granular positivity in the tumor cells cytoplasm, which is abolished by d-PAS staining (not shown). PAS, $\times 400 ; \mathrm{F}-\mathrm{H}$ : immunohistochemistry of tumor cells. The tumor cells were positive for cytokeratin $7(F), C E A(G)$, and MUC1 $(H)$. Immunostainings, $\times 200$.

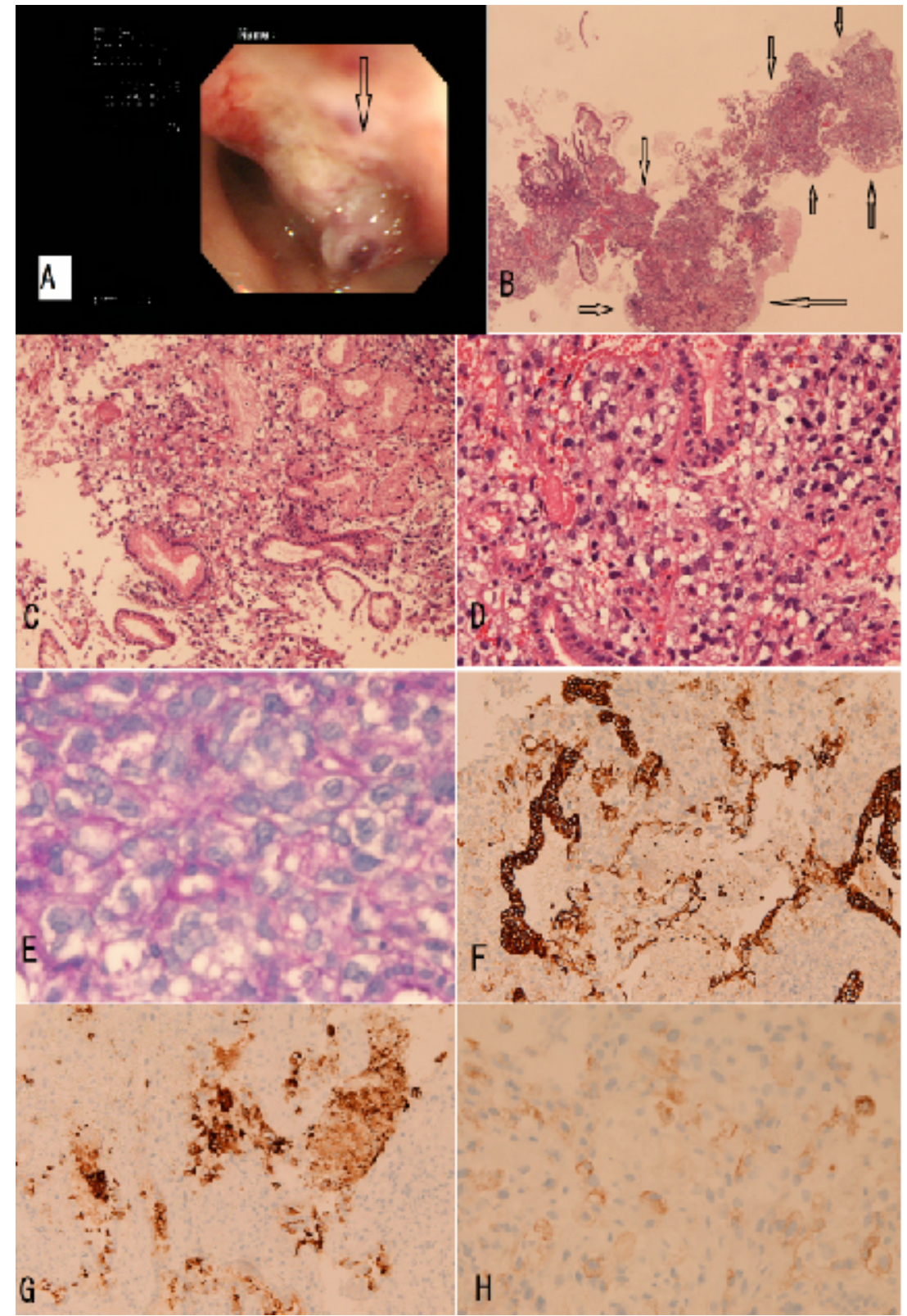

nocarcinoma, squamous cell carcinoma NOS, arcinoma, and undifferentiated NOS. Thus, the WHO ICD-O classification does not show CCA of duodenum, reflecting that duodenal CCA is very rare.

In general, the clearness of clear cell tumors is due to accumulations of fat, mucus, body fluid, or glycogen. The clear cytoplasms of the present tumor seems due to glycogens. Accumulation of fat or glycogen push nuclei into the unknown primary site, signet ring cell carcinoma, adenosquamous carcinoma, medullary carcinoma NOS, medullary ade- 
periphery, thus creating signet-ring cell carcinoma (mucus) and lipid cells (fat). In general, glycogen accumulation does not cause nuclear displacement. Although no fat stain was possible in the present tumor, the clearness is not due to fat. No mucus was found in the present tumor by several mucus stains, suggesting that the cytoplasmic clearness of the present tumor is not ascribed to mucins. Accumulation of body fluid in the cytoplasma (intracytoplasmic edema) which is seen in necrodegenerative assault, can showed clear cytoplasma, but this situation also shows other degenerative change and necrosis, which are not present in the present case. The clear cytoplasm of most CCA including gastric $\mathrm{CCA}^{[5]}$ is owing to glycogen accumulation. ${ }^{[2-7]}$ The present tumor is not signet-ring cell carcinoma.

Though the present tumor is primary duodenal tumor, other tumors showing clear cytoplasma, particularly clear-cell RCC, clear cell variant of hepatocellular carcinoma (HCC), and CCA of female genital organs and peritoneum, should be excluded. The present tumor had no tumors in such locations; thus it is concluded that the present case is not among these tumors. Immunohistochemical data of negative CD10 and RCC marker suggest that the present tumor is not RCC, negative AFP and HepPar1 not HCC, and negative ER, PgR, CA125 not CCA of female genital organ.

Since CCA can arise from most organs, the present study employed an Immunohistochemical study. The cytokeratin pattern (CK7+, CK18+, CK19+, CK20-, CK34BE12, CK5, and CK6) is compatible with primary gastrointestinal tumor. The positive CEA, CA19-9 and MUC1 is compatible with the conclusion that the primary tumor is basically adenocarcinoma though the tumor was very poorly differentiated. The positive p53 and high-Ki-67 indicate malignancy of the tumor

\section{REFERENCES}

[1] Terada T. Malignant tumors of the small intestine: a histopathologic study of 41 cases among 1,312 consecutive specimens of small intestine. Int J Clin Exp Pathol. 2012; 5: 203-9. PMid: 22558474.

[2] Terada T. Pathologic observations of the duodenum in 615 consecutive duodenal specimens in a single Japanese hospital: II. malignant lesions. Int J Clin Exp Pathol. 2012; 5: 52-7. PMid: 22295147.

[3] Terada T. Protein expression and gene mutation status of KIT and PDGFRA in renal cell carcinoma. Histol Histopathol. 2012; 27: 297 302. PMid: 22237707

[4] Terada T. Clear cell adenocarcinoma of the ovary arising in atypical endometriosis: a report of eight cases. Arch Gynecol Obstet. 2012; 285: 229-33. PMid: 21594603. http://dx.doi.org/10.1007/s 00404-011-1929-3

[5] Terada T. Pure glycogen-rich clear cell adenocarcinoma of the stomach. J Gastrointest Cancer. 2014; 45: 372-6. PMid: 23673917. http://dx.doi.org/10.1007/s12029-013-9482-x

Published by Sciedu Press and positive p53 mutations. Other negative immunohistochemical markers have many meanings, but it only stated herein that the tumor is not prostatic adenocarcinoma which occasionally shows clear cytoplasm, is not primary lung carcinoma, is not malignant lymphoma, does not have neuroendocrine differentiation, does not have secretory MUC, and is not breast carcinoma.

The clinical significance of CCA of duodenum is now uncertain, as with the case in many clear cell tumors. However, the tumor shows characteristic histological and Immunohistochemical features. Although the author does not prefer increasing over-classifications, being done by many institutions (such as WHO, AFIP), whose clinico-pathological entities are uncertain, the author feels that CCA of duodenum can provide specific clinico-pathological correlations useful as it specific clinico-pathological entity. Thus, observational studies of this tumor after case accumulations may be worthy.

Finally, as is well known, gastrointestinal adenocarcinoma can show many patterns of co-existing structures including tubular, acinar, papillary, poorly differentiated, mucinous, signet-ring cell, and anaplastic. In the present study, no surgical treatment was done, and therefore the whole histological features were not obvious. However, the seven relatively large punch biopsies showed CCA without obvious features of other types of gastrointestinal adenocarcinoma phenotype. Therefore, the author thinks that it is authentic CCA of duodenum.

\section{Conclusion}

The first case of primary CCA of duodenum is reported.

\section{CONFLicts of InTEREST Disclosure}

The author declares no conflict of interest.
[6] DeLair D, Oliva E, Köbel M, et al. Morphologic spectrum of immunohistochemically characterized clear cell carcinoma of the ovary: a study of 155 cases. Am J Surg Pathol. 2011; 35: 36-44. PMid: 21164285. http://dx.doi.org/10.1097/PAS.0b013e3 $181 \mathrm{ff} 400 \mathrm{e}$

[7] Gobbo S, Eble JN, Grignon DJ, et al. Clear cell papillary renal cell carcinoma: a distinct histopathologic and molecular genetic entity. Am J Surg Pathol. 2008; 32: 1239-45. PMid: 18594469. http://dx.doi.org/10.1097/PAS. Ob013e318164bcbb

[8] Terada T, Kawaguchi M, Furukawa K, et al. Minute mixed ductalendocrine carcinoma of the pancreas with predominant intraductal growth. Pathol Int. 2002; 52: 740-6. PMid: 12685552. http: //dx.doi.org/10.1046/j.1440-1827.2002.01416.x

[9] WHO. International Classification of Disease for Oncology. ICD-O-3 Online. Available From: http://codes.iarc.fr/topography /C17.0 